DOI: 10.15290/bsp.2017.22.01.en.12

Maciej Fingas

\title{
Orzekanie reformatoryjne w instancji odwoławczej w polskim procesie karnym [Powers to alter decisions under appeal in the Polish criminal trial] \\ Wolters Kluwer Publishing House, Warszawa 2016, pp. 366
}

The monograph of Maciej Fingas, $\mathrm{PhD}$, titled "Powers to alter decisions under appeal in the Polish criminal trial" ${ }^{1}$ is an interesting and comprehensive proposal presenting powers of appellate courts to alter decisions in the Polish criminal procedure.

The monograph under review is a brief and up-to-date version of the author's $\mathrm{PhD}$ dissertation defended by him in 2014 in the Faculty of Law and Administration of the University of Gdańsk supervised by UG Prof. dr. hab. Sławomir Steinborn.

The monograph presents a significant issue of the evolution of a possibility to alter decisions by courts in result of the amendments implemented by the legislator in 2013-2016, thanks to which the monograph is up-to-date.

Already in the introduction to his paper, the author focused on the essence of the subject matter pointing out to the need of a proper development of measures of appeal, which is now "one of the most important guarantees of the proper operation of the administration of justice" (p. 13).

The monograph under review is composed of four well thought and interesting chapters divided into sub-chapters.

The first chapter titled "Model conditions of appellate control in criminal proceedings" encompasses both historical and comparative legal issues, and refers to the model of appellate proceedings in the civil procedure.

1 M. Fingas, Orzekanie reformatoryjne $\mathrm{w}$ instancji odwoławczej $\mathrm{w}$ polskim procesie karnym, Warszawa 2016. 
At the beginning of this chapter, the author explains terminology of notions and definitions used therein, and discusses the functions of instance control. Analyzing the model of appellate proceedings, he rightly claims that: "It may be concluded that a choice the legislator faces involves, most of all, appropriate distribution of emphases with regard to powers referring to the substantive scope of examination of cases and types of rulings rendered by appellate courts. Nevertheless, it is equally important for the court to be equipped with instruments adequate to the tasks it is entrusted with" (p. 27).

In the first chapter the author considers historical issues affecting development of the Polish appellate system. Analyzing the appellate court's powers in the pre-war system of appeal and cassation in 1928-1949, in the system of review in 1949-1989 as well as in 1989-2013 and after 2013, the author focuses on the most important and essential issues connected with, among others, the parties, taking evidence by the court and potential types of appellate court's rulings.

A part of the first chapter devoted to the structure of the system of judicial control (sensu largo) operating in other countries should also be paid attention to. The author depicts criminal appealing procedure within the above scope existing in France, Belgium, Italy, Germany, Russia, Great Britain, the USA and Japan (p. 4248). As far as models of appellate proceedings in the context of comparative law are concerned, the author described those operating in France, Great Britain, Germany, Russia and Japan. The only thing that may slightly distract a potential reader is a lack of divisions between descriptions of individual models in other countries, due to which the information about a specific model is not classified and one needs "to return" to the model described earlier by the author (e.g. "Coming back to the French system..." p. 51, "It has been mentioned before that in the British procedure..." p. 53).

Characterizing models of review proceedings, the author focused on the institution of review in Germany describing the issues of appellate claims assessed by the review court quite precisely (p. 56-58). What is more, he pointed out to cassation in Russia as a typical measure of appeal in this model and, to some extent, to the Polish appeal procedure in the normative shape before 1 July 2015, as well as to the Italian appeal procedure.

The author depicted the institution of cassation in France as a standard of cassation, which "once created has then become a base of a theoretical model of cassation review imitated many a time in the systems of other countries, e.g. in Holland, Belgium, Spain, Italy and Poland" (p. 61). Furthermore, the author notices that: "In the common law systems, appellate proceedings are carried out in a special way while typical mechanisms of appellate courts' processing often bring these proceedings closer to the cassation model in respect of their nature" (p. 62). Reference to J. Dressler's research on data from the State of California is significant 
Powers to alter decisions under appeal in the Polish criminal trial

and interesting. According to it, as many as $95 \%$ of appeals submitted in favour of the defendant are dismissed by a court of appeal ${ }^{2}$.

Attention should also be paid to an extremely interesting issue of an outlined model of appellate proceedings in the civil law procedure, which closes chapter one (p. 63-72). In this respect, the author's words from the introduction should be quoted: "In any case, it seems that the shape of appellate proceedings in civil cases, which has been successfully applied for many years, may be a certain inspiration for the interpretation of valid provisions as well as considerations of their future shape. A greater impact on adversarial proceedings may indeed bring both procedures closer in certain spheres" (p. 17). In this part, the author admitted himself that he limited the above considerations to "the principal standard issues of civil appellate proceedings" (p. 65).

In the second chapter titled "Admissible limits of appellate court's powers to alter decisions in the light of the selected principles of a criminal trial", the author analyzed eight selected procedural rules, namely: the principle of two-tiered jurisdiction, the principle of substantive reality, the right to defence, direct adduction, free assessment of evidence, expeditious proceedings and the principle of adversarial proceedings.

At the beginning of the second chapter the author emphasized that "it appears that the current paradigm of a criminal trial is designated by principles understood as general directives expressing basic and typical features and regularities of a criminal trial" (p. 73). The author rightly points out to the dynamics of procedural principles which evolve over time and changing ideologies (p. 74). The author believes that the choice of individual procedural principles to be analyzed in the context of appellate court's power to alter decisions was a result of the relation between these principles and the model of appellate proceedings. The author claims that "the model of procedure must be subject to evaluation expressed through the prism of the standard of a fair criminal trial that has been mainly developed by the ECHR's case law. In this respect, however, it is not necessary to carry out a separate analysis on the level parallel to this created by fundamental principles of a criminal trial" (p. 76).

In the second chapter, the author also analyzes a relation between these selected procedural principles and elements of the model of appellate proceedings referring to the case law of the Supreme Court, Constitutional Tribunal and ECHR.

An interesting sub-chapter devoted to cassation rulings as one of the reasons for the protraction of proceedings should receive equal attention too. Statistical data of the Ministry of Justice for 2007-2012 as well as A. Zachuta's ${ }^{3}$ research encompassing the analysis of judgments of the Regional Court in Cracow presented in this part

2 J. Dressler, Understanding Criminal Procedure, Newark-San Francisco 2002, p. 65.

3 A. Zachuta, Kasatoryjne orzeczenia w odniesieniu do wyroków wydanych w sprawach karnych przez sądy rejonowe, „Prokuratura i Prawo” 2006, No. 6, p. 67. 
of the paper provide significant information about a number of cassation rulings (p. 143-145).

The author also discusses the research of case files conducted by D. Wysocki in the Regional Court in Płock ${ }^{4}$, which imply that the abandonment of the classical model of appeal allowed to shorten an appeal trial, but in cases where cassation ruling was passed, the proceedings were noticeably prolonged (p. 146-147). Summing up this part of the paper, a quite bold statement made by the author should be quoted here, according to which "opinions claiming that the model of review proceedings prevail over the model of appeal with regard to the speed of a trial should be discarded" (p. 150). Hence the author supports the opinion of hearing a case within the limits of appeal.

The third chapter "Conditions of sentencing in the context of the power to alter a decision in appellate jurisdiction" is divided into six sub-chapters which concern relations between collected evidence in the first instance proceedings and a possibility of altering a decision, obtaining a consent for a change of the judgment passed in effect of the consensus, a type of failure of the judgment under appeal, limits of hearing a case in appellate proceedings, ne peius bans, and a complaint against the court of appeal's judgment.

Already at the beginning of chapter three the author states that "changes implemented within the scope of appellate proceedings ensue confrontation of old assumptions and contemporary realities as well as up-to-date trends in the development of a criminal trial, which especially encompass the idea of actual increase of adversarial proceedings and hasten proceedings while preserving necessary procedural guarantees of their participants" (p. 160-161).

In respect of the analysis of explanation of the facts of a case and a possibility of hearing evidence in appellate courts, the author righty states that "a solution known in civil appellate proceedings has been adopted" (p. 171) following the example of Art. $386 \S 4$ of the CCP. Further considerations in this part focus on admissibility of hearing of evidence by a court of appeal, and make interesting comparisons to a civil trial (p. 188).

Interesting but quite controversial comments are included in the sub-chapter about obtaining the parties' consent to change a judgment passed in effect of the consensus. The author made a debatable statement, according to which "the results of the above problem's analysis in the literature [within the scope of limiting grounds for appeal related to appealing against judgments passed in effect of the consensus - added by I.U.-M.] confirm that the narrowed control of appeals by the limited catalogue of the grounds for appeal may be admissible if it is strictly connected with a given procedural institution and justified by the nature of this institution. (...) The 
implemented regulation satisfies the above conditions (...)" (p. 198). We should also consider right critical arguments against the author's claim - a possibility of infringing procedural guarantees of the party that withdrew from the concluded settlement and then would like to appeal against the judgment passed in effect of the consensus ${ }^{5}$.

Another interesting sub-chapter depicts types of failures (errors of law) the judgment under appeal is affected by. At the beginning of this sub-chapter, the author underlines an important role played by the grounds for appeals reminding that "a basic function of control (audit) proceedings is their corrective function, i.e. a task to correct defective rulings by their reversal or change" whereas "the object of the court's corrective activity ad quem are the so called grounds for appeal defined in the doctrine as any failures (errors of law) of the first instance court which may be interesting from the perspective of control proceedings and constitute the grounds for appropriate decisions of a court of appeal" (p. 200-201). In a further part of this sub-chapter, the author quite briefly describes relative (p. 202-218) and absolute (p. 218-230) grounds for appeal. The author presents an apparently interesting opinion on the new absolute ground for appeal under Art. $439 \$ 1$ point 1a of the CCP introduced since 1 January 2017 (wrongly indicated by the author in Art. 439 $\$ 1$ a of the CCP - p. 221).

Further parts of chapter three contain important and generally detailed issues connected with the limits of hearing a case by a court of appeal (p. 230-266) and ne peius bans (p. 266-296) as well as a new institution of a complaint against the appellate court's judgment (p. 296-298).

In the fourth chapter titled "Powers to alter decisions in appeals", the author describes in two sub-chapters both the limits of corrections made by the appellate instance and the conditions of powers to alter decisions by the appellate authority.

Already at the beginning of this chapter the author notices that "it is beyond any doubts that issues connected with the control of judgments enjoy the highest status among procedural decisions taking the foreground of appellate control" (p. 299), and points out to the essence of limits of corrections made by the appellate authority. Moreover, considerations within this matter through the prism of norms existing in the civil procedure (e.g. p. 304) appear interesting. On the other hand, in respect of the conditions of powers to alter decisions by the appellate authority, the author refers to the Code of Criminal Procedure of 1928, which did not include regulations

5 C. Kulesza, Zaskarżanie wyroków zapadłych w trybach konsensualnych - standard europejski i prawo polskie, „Białostockie Studia Prawnicze” 2014, No. 1, p. 108; I. Urbaniak-Mastalerz, Podstawy apelacji w znowelizowanym kpk. (uwagi na tle wyników badań aktowych, (in:) Środki zaskarżenia po nowelizacji kodeksu postępowania karnego, A. Lach (ed.), Toruń 2015, p. 104, I. Urbaniak-Mastalerz, Współczesny paradygmat wykładni prawa karnego, "Monitor Prawniczy" 2015, No. 24, p. 1317; I. Urbaniak-Mastalerz, Pozycja oskarżonego w nowym modelu postępowania odwoławczego, (in:) Postępowanie odwoławcze w procesie karnym - u progu nowych wyzwań, S. Steinborn (ed.), Warszawa 2016, pp. 226-230. 
indicating directly what rulings may be rendered in effect of the appellate control (p. 309).

Although chapter four may seem slightly shorter than the other chapters (it is only 29 pages long), the analysis conducted therein encompasses the most important aspects supported by coherent and explicitly formulated conclusions.

The author's conclusions (p. 329-338) contain important and interesting considerations summing up the monograph under review. The author notices that "the discussion on the current shape of appellate proceedings is considerably affected by the ideas on review proceedings, which have changed our attitude to the appeal system for many years. Normative solutions introduced by the amendment of 1949 have been in force until now while social and political reality was completely different at that time" (p. 329).

The author's de lege ferenda postulates closing the monograph should also be paid attention to as they enrich its merits and scientific message.

Multitude of important aspects discussed by the author, reference to numerous other regulations, many normative comparisons between a criminal and civil trial as well as extensive bibliography and the so called simple language of the work make the monograph not only interesting but also extremely helpful in solving problems connected with the prerequisites to alter a judgment under challenge by a court of appeal.

The monograph "Powers to alter decisions under appeal in the Polish criminal trial" can be absolutely recommended to every reader as it is a rich source of information about the model of appellate proceedings including extremely interesting author's considerations, ideas and opinions. 